\title{
GASTRIC VOLUME AND pH IN OUT-PATIENTS
}

\author{
Bill Y. Ong, Richard J. Palahniuk and maureen Cumming
}

ASPIRATION of gastric contents into the tracheobronchial tree is a major cause of anaesthesia-related morbidity and mortality. ${ }^{1-4}$ Clinical experience suggested that patients with a large volume of gastric contents were more susceptible to regurgitation and aspiration during anaesthesia. Since out-patients have less preparation and supervision than patients in hospital prior to operation, the out-patients may have a greater volume of gastric content and greater risk of aspiration. Since the gastric content of outpatients had not been studied previously, we measured and compared the volume and $\mathrm{pH}$ of gastric content of out-patients and in-patients undergoing general anaesthesia for minor surgical procedures.

\section{Method}

This study was approved by the University of Manitoba Human Studies Committee. After obtaining informed consent, 21 out-patients and 21 in-patients undergoing minor surgical procedures were studied. The operations included dental extractions, tubal ligations and diagnostic dilatation and curettage. No pregnant patients were included in the study. All patients were young, female and had no pre-existing gastrointestinal diseases. All out-patients were given written instructions not to eat or drink after midnight on the day of their operations. All in-patients were kept fasting after midnight prior to their operations. No patient received premedication. All anaesthetics consisted of thiopentone induction, succinylcholine paralysis, tracheal intubation, and nitrous oxide/oxygen/halothane maintenance. After induction, a gastric tube was passed orally into the stomach and $5 \mathrm{ml}$ of gastric fluid was withdrawn for $\mathrm{pH}$ determination. Polyethylene glycol (PEG) $50 \mathrm{ml}$ was then injected into the stomach for determination of gastric volume by the dilution method. PEG is a non-toxic, non-

Bill Y. Ong, M.D., Richard J. Palahniuk, M.D., and Maureen Cumming. Department of Anaesthesia, University of Manitoba, Health Sciences Centre, 700 William Ave., Winnipeg, Manitoba, Canada, R3E 0Z3.

Presented at the Annual Meeting, Canadian Anaesthetist's Society, Saskatoon, Saskatchewan, June, 1977. absorbable, water soluble polymer. After mixing by suction and reinjection several times, the gastric content was aspirated as completely as possible with a large syringe. The gastric tube was then removed.

The $\mathrm{pH}$ of the gastric fluid was measured with an appropriately calibrated $\mathrm{pH}$ electrode. The PEG concentration in the diluted gastric content was determined by a tubidimetric method. ${ }^{5}$ Knowing the initial concentration, initial volume, and the final concentration, the volume of gastric fluid diluting the PEG could be calculated. The dilution method has been used to determine bowel volumes in gastrointestinal absorption studies and has been found to be accurate. ${ }^{6,7}$

Age, weight, number of hours fasting, calculated gastric volume and $\mathrm{pH}$ of the two groups were compared using Student's t-test for unpaired data. The $\mathrm{pH}$ values were converted to hydrogen ion concentration for statistical calculations and the results changed back to $\mathrm{pH}$ units for presentation. The volume of gastric juice aspirated was compared with the calculated gastric volume to assess the accuracy of the aspiration method in determining gastric volumes.

\section{RESULTS}

The two groups of patients were similar in age and weight (Table I). The in-patients had fasted for an average of $15 \pm 0.6$ hours, the out-patients $12 \pm 0.5$ hours. The out-patients had larger gastric volumes, averaging $69 \pm 17 \mathrm{ml}$, while inpatients had an average of $33 \pm 4 \mathrm{ml}$ (Figure 1). There was no statistically significant correlation between the gastric volume and the duration of fast, the type of operation, or the time of day when the patient was studied. The gastric $\mathrm{pH}$ values were similar in both groups with an average of $1.8 \pm 0.2$ for out-patients and $2.0 \pm 0.3$ for in-patients. The frequencies of occurrence of large gastric volumes among the in-patients and out-patients are shown in Figure 2.

The correlation between the amounts of gastric juice aspirated through a gastric tube and the gastric volumes determined by the dilution method was poor (Figure 3). In many instances there were large differences between the two val- 
TABLE I

age, Weight and Time Fasted for Hospital In-Patients and Out-Patients

\begin{tabular}{lcccc}
\hline \hline & \multicolumn{2}{c}{ In-patients } & \multicolumn{2}{c}{ Out-patients } \\
& Mean \pm S.D. & Range & Mean \pm S.D. & Range \\
\hline Age (years) & $28 \pm 0.9$ & $22-34$ & $29 \pm 1.4$ & $20-43$ \\
Weight (Kg) & $55 \pm 6$ & $52-69$ & $59 \pm 8$ & $52-78$ \\
Time fasted (hours) & $15 \pm 0.6$ & $9-16$ & $12 \pm 0.5^{*}$ & $8-18$ \\
\hline$* \mathrm{P}<0.05$ & & & &
\end{tabular}

ues, the volume aspirated being frequently much less than the volume calculated. The negative values for the volume suctioned occurred when the amount aspirated was less than the volume of PEG initially injected into the stomach.

\section{Discussion}

The large acidic gastric volumes of outpatients have not been demonstrated previously. These findings may be explained by the small amount of preparation and supervision the outpatients received prior to operation. These patients do not have a visit from their anaesthetist the day before operation, or pre-operative medication to help alleviate anxiety. The emotional strain associated with hospitalization and apprehension about the up-coming operation may disturb gastric motility and increase gastric acid secretion ${ }^{8}$ Steroids, ACTH and epinephrine given in amounts similar to those released by the body under stress increase the amount and acidity of gastric secretions. ${ }^{9-12}$ In addition, some individuals may eat or drink before coming to hospital, despite specific instructions about fasting.

Premedication with anticholinergics, narcotics and barbiturates, in sufficient doses to reduce gastric secretion and patient anxiety, will also

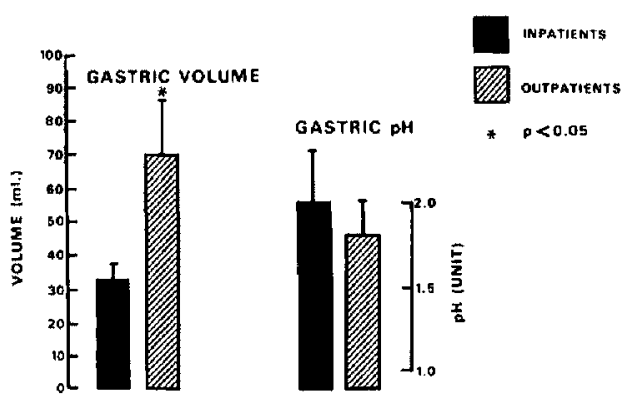

Figure I Mean gastric volume and $\mathrm{pH}$ of the hospital in-patients and out-patients. delay gastric emptying. ${ }^{3}$ Christensen and Skovsted found that premedicated patients still had an average of $22 \mathrm{ml}$ of gastric fluid of $\mathrm{pH}<3.0$. $^{14}$

If we accept the suggestions of Teabeaut ${ }^{15}$ and

DISTRIBUTION OF GASTRIC VOLUMES

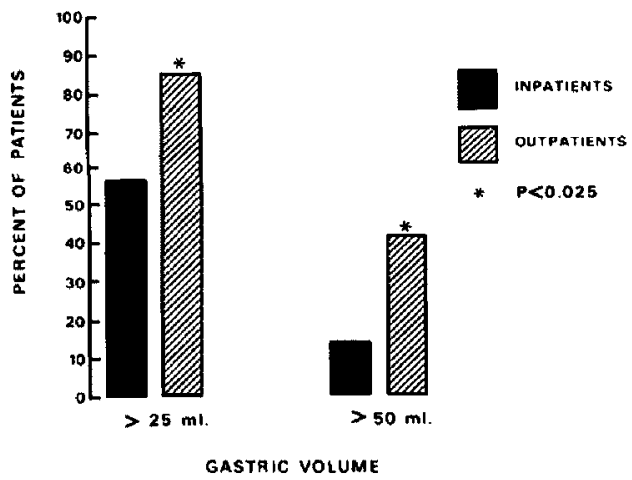

Figure 2 Frequencies of occurrence of large gas. tric volumes among the hospital in-patients and outpatients.

VOLUME SUCTIONED VS. VOLUME CALCULATED

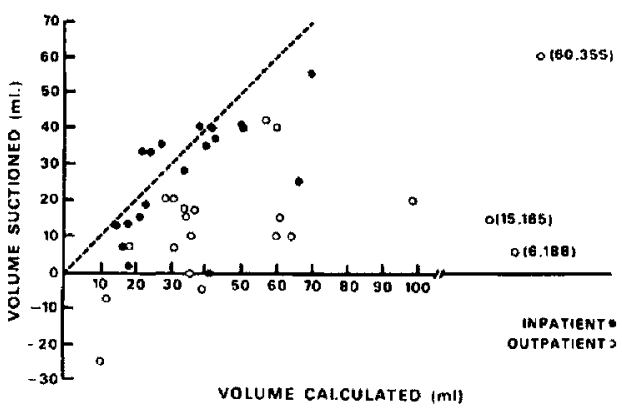

FIGURE 3 Relationship between gastric volumes determined by the dilution method and aspiration method. In three cases, the values were off the scale, so the actual values were given in brackets. The negative values for the volume suctioned occurred when the amount aspirated was less than the volume of polyethylene glycol initially injected into the stomach. 
TABLE II

Out-Patients at High Risk

\begin{tabular}{|c|c|c|c|c|c|}
\hline Patient & $\begin{array}{c}\text { Gastric } \\
\text { Volume } \\
\text { (ml) }\end{array}$ & $\begin{array}{l}\text { Gastric } \\
\text { pH (units) }\end{array}$ & $\begin{array}{c}\text { Age } \\
\text { (years) }\end{array}$ & $\begin{array}{c}\text { Weight } \\
(\mathrm{kg})\end{array}$ & $\begin{array}{c}\text { Hours } \\
\text { NPO }\end{array}$ \\
\hline 1 & 165 & 1.6 & 27 & 57 & 8 \\
\hline 2 & 188 & 1.6 & 20 & 50 & 12 \\
\hline 3 & 355 & 1.9 & 27 & 57 & 15 \\
\hline 4 & 98 & 1.7 & 31 & 58 & 15 \\
\hline
\end{tabular}

of Roberts and Shirley ${ }^{16}$ that aspiration of more than $25 \mathrm{ml}$ of fiuid of $\mathrm{pH}$ less than 2.5 by a normal woman would produce acid pneumonitis, then 28 of the 42 patients in our study had sufficient acidic gastric juice to cause acid pneumonitis if the total gastric volume was aspirated. Four of these patients had gastric volumes over $75 \mathrm{ml}$ (Table II). All were in the out-patient group. Three patients had volumes of $188 \mathrm{ml}, 165 \mathrm{ml}$ and $355 \mathrm{ml}$ and would be considered to be at extreme risk for regurgitation and aspiration. These patients could not be distinguished from the other patients by their reported duration of fast, age or weight. Therefore, many patients coming for operation, especially out-patients, have a large amount of acid gastric juice which, if aspirated, may lead to great morbidity and even mortality. The danger from such gastric content can be minimized by emptying the stomach or neutralizing the acid content.

The stomach can be emptied by an emetic such as apomorphine, but such an approach is too barbaric. Aspiration through a wide-bore stomach tube can remove most of the gastric content, but a significant residual may be left. In our study, the suctioned volumes of gastric content were often much less than those determined by the dilution method.

Taylor and Pryse-Davies ${ }^{17}$ showed that $14 \mathrm{ml}$ of magnesium trisilicate raised the gastric $\mathrm{pH}$ above 2.5 in obstetrical patients. This is a simple, inexpensive and convenient way of reducing the risk of acid-aspiration pneumonitis.

In conclusion, the finding of such great quantities of acid gastric contents in out-patients suggest that they are at greater risk for regurgitation and aspiration during anaesthesia. Aspiration through a gastric tube will not empty the stomach completely and the volume thus obtained will provide a falsely low estimate of the gastric volume. The administration of oral antacid to all patients before anaesthesia should be considered.

\section{SUMMARY}

We measured the volume and $\mathrm{pH}$ of the gastric content of 21 out-patients and 21 in-patients under general anaesthesia. Gastric tubes were inserted after induction of anaesthesia, and gastric fluids were withdrawn for $\mathrm{pH}$ determinations. Gastric volumes were measured by a dilution technique using polyethylene glycol as the indicator and also by measurement of the volume aspirated through a gastric tube. Out-patients had a mean gastric volume of $69 \pm 17 \mathrm{ml}$ while inpatients had a mean volume of $33 \pm 4 \mathrm{ml}$. The average gastric $\mathrm{pH}$ for the out-patients was $1.8 \pm$ 0.2 and for the in-patients $2.0 \pm 0.3$. Four outpatients had more than $75 \mathrm{ml}$ of gastric fluid of $\mathrm{pH}$ less than 2.0. Aspiration through a gastric tube did not empty the stomach completely and the volume thus obtained gave a falsely low estimate of the gastric volume.

\section{RÉSUMÉ}

Nous avons déterminé le $\mathrm{pH}$ et le volume du liquide gastrique chez 21 malades hospitalisés, opérés sous anesthésie générale, et chez 21 autres patients ambulatoires, soumis à une anesthésie générale pour chirurgie. A cet effet, nous avons mis en place une sonde naso. gastrique avant l'induction de l'anesthésie et avons prélevé du liquide gastrique pour en déterminer le pH. Nous avons également fait la mesure du volume liquidien gastrique au moyen d'une technique de dilution, le polyéthylène glycol servant d'indicateur, ainsi que par la mesure directe du volume total que nous pouvions aspirer.

Les malades ambulatoires avaient un volume moyen de $69 \pm 17 \mathrm{ml}$, alors que les patients hospitalisés avaient un volume de $33 \pm 4 \mathrm{ml}$. Le $\mathrm{pH}$ du liquide gastrique des malades non hospitalisés était de $1.8 \pm 0.2$, alors qu'il était de $2.0 \pm 0.3 \mathrm{chez}$ les malades hospitalisés. Quatre des patients ambulatoires avaient plus de $75 \mathrm{ml}$ de liquide dans l'estomac et à un pH de moins de 2.0. La succion appliquée à la sonde naso-gastrique ne permettait pas de vider complètement l'estomac et les vo. lumes ainsi obtenus donnaient des résultats inférieurs à la réalité.

\section{REFERENCES}

1. Bannister, W.K. \& Sattil.aro. A.J. Vomiting and aspiration during anesthesia. Anesthesiology $23: 25$ (1962). 
2. Clifton, B.S. \& Hotten, W.I.T. Deaths associated with anaesthesia. Br. J. Anaesth. 35: 250 (1963).

3. Dinnick, O.P. Deaths associated with anaesthesia. Observations on 600 cases. Anaesthesia 19 : 536 (1964)

4. Edwards, G., Morton, H.J.V., Pask, E.A., \& WYLIE, W.D. Deaths associated with anaesthesia A report on 1000 cases. Anaesthesia 11: 194 (1956).

5. Malawar, S.J. \& Powell, D.W. An improved turbidimetric analysis of polyethylene glycol utilizing an emulsifier. Gastroenterology 53: 250 (1967).

6. Bloom, D.S., Jacobson, E.D., \& Grossman, M.I. Validation of dilution indicators in the stomach. Gastroenterology 52: 205 (1967).

7. IVEY, K.H. \& ScheDL, H.P. Gastric nonabsorbable indicators for studies in man. Gastroenterology 59: 234 (1970).

8. GuYton, A.C. Textbook of Medical Physiology Philadelphia: W.B. Saunders Co., p. 876 (1976).

9. Chalkof, L., Janke, W.H., Pesaros, P.C. Panka, J.L., \& Brush, B.F. Effects of Prednisone and Corticotropin on gastric secretion. Arch. Surg. 83: 32 (1961).

10. Gray, S.J., Benson, J.A., \& Reifenstein, R.W. Chronic stress and peptic ulcer. l. Effect of corticotropin (ACTH) and cortisone on gastric secretion. J.A.M.A. 147: 1529 (1951).
11. Menguy, R.\& MAsters, Y.F. Effects of cortisone on mucoprotein secretion by gastric antrum of dogs: pathogenesis of steroid ulcer. Surgery $54: 19$ (1953).

12. Christensen, K.C. \& Stadil, F. Effect of epinephrine and norepinephrine on gastric release and gastric secretion of acid in man. Scand. J. Gastroenterology Suppl. 37: 87 (1976).

13. GoOdMAN, L.S. \& GiLMaN, A. The pharmacological basis of therapeutics. New York: Macmillan (1976).

14. Christensen, V.\& Skovsted, P. Effects of general anaesthetics on the $\mathrm{pH}$ of gastric contents in man during surgery: a survey of halothane fluoroxene and cyclopropane anaesthesia. Acta Anaesth. Scand. 19: 49 (1975).

15. Teabeaut, J.R. Aspiration of gastric content: an experimental study. Am. J. Pathol. 28:51 (1952).

16. Roberts, R.B. \& SHI RLEY, M.A. Reducing the risk of acid aspiration during cesarean section. Anesth. \& Analg. 58:859 (1974).

17. TAYLor, G. \& Physe-Davies, J. The prophylactic use of antacids in the preventive treatment of acid-pulmonary-aspiration syndrome. Acta Anaesthesiol. Scand. Suppl. 25: 399 (1966). 